\title{
PIEE
}

Premise: Journal of English Education and Applied Linguistics

https://fkip.ummetro.ac.id/journal/index.php/english

Anum and Apriyanto

\section{DETECTING GENDER'S STRATEGIES IN LEARNING SPEAKING}

\section{Adelina Anum \\ ORCID ID: https://orcid.org/0000-0003-0915-9790}

University of Sang Bumi Ruwa Jurai, Faculty of Social and Political Science, Bandar Lampung

punya.adel@gmail.com

Sigit Apriyanto

Universiti Tun Hussein Onn Malaysia, Faculty of Applied Science and Technology, Malaysia sigitteduh89@gmail.com

Received: January 22, 2019

Sent back: January 24, 2019,

Reviewed: March 27, 2019
Reviewed: January 23, 2019

Accepted: February 25, 2019

Published: April 2, 2019

\begin{abstract}
:
The researchers intended to know what strategies were used by male and female students in learning speaking, especially at the tenth grade of SMKN Karangpucung and what dominant strategy was used by male and female students in learning speaking. The main question to be answered in this research was concerned with the strategy used by male and female students and what the dominant strategy used by male and female students. The population in this research were 320 students at the tenth grade of SMKN Karangpucung consisting of automotive and accountancy programs, and 32 students were taken as the sample. The instrument used to collect data was a questionnaire consisting of 30 questions to determine the students' strategies used by every male and female student. This research showed that male students tended to use metacognitive strategies and female students tended to use affective strategies. Therefore, the researchers concluded that metacognitive strategies are more likely to be used by male students and affective strategies are more likely to be used by women students. Surprisingly, metacognitive strategies were dominated by male students, while affective strategies were dominated by female students.
\end{abstract}

Keywords: Learning Strategies, Gender on Education, English for SMK, Learning Speaking.

\section{INTRODUCTION}

A large percentage of language learners study English in this world in order to develop their proficiency in speaking. "Learning speaking as foreign language

Premise Journal Vol. 8 No 1, April 2019, e-ISSN: 2442-482x, p-ISSN: 2089-3345, page 58-72

Copyright@2019 by PJEE 
particularly English is not easy, which is hardly difficult to mastery by the learners (Umar and Suparman, 2018, p.58)." Someone who was willing to master English needs to learn more about language skills, like learn about the way in introducing the words, spelling the words, remembering the words that will be applied in communication. In the study by Boeriswati (2012), it was found that successful learners appear to use learning strategies more frequently and in qualitatively different ways than learners who are less successful. In other words, the student's success in learning English is strongly influenced by the learning strategy. Therefore, appropriate learning strategies have an influence in determining the process and student learning goal.

Aslan (2009) states language learning strategies are behavior or actions which learners use to make language learning more successful, self-directed and enjoyable. There are differences between male and female role. Females have typically been expected to be sensitive, intuitive, passive, emotional, and naturally interested in household chores and child-rearing. Furthermore, females tend to be more openminded, open to persuasion, lower in performance specific self-esteem than males, but not lower in general self-esteem and females are evaluated on criteria such as emotional warmth and sociability. It can be assumed that even females' self-esteem seems to be lower than that of males, females can increase their communicative behaviors during students' discussion (Saputra, 2018).

Another line of the research conducted by Sabbatini (1997) shows that women can use the language as a means of communication widely than men. In fact, those women always spend their time with a friend just for talking about others. They use a variation of language, from the daily language to the specific one that only understandable among themselves. When male and female students interact with the teacher during the teaching and learning process, it shows that they have different strategies in learning, especially in learning speaking.

On the other hand, Baalen (2001) explains that women talk more, give more information and are more concerned with someone's feelings. The male language was reported to show "control", for example by the use of short sentences. Furthermore,

Premise Journal Vol. 8 No 1, April 2019, e-ISSN: 2442-482x, p-ISSN: 2089-3345, page 57-72 Copyright@2019 by PJE 
Romaine (2008) believes that women speaking in more formal conversation is closest to the standard and never use the non-standard form. In contrast, Kiesling (2008) explains that men are more focused on solidarity in the socializing situation, and more on power in the interview and meeting situations. In other words, men are more likely to pay attention to the state environmental situation to determine what they should say. In addition, the male uses his voice and intonation power to convince the listener and less attention to the patterns or grammatical sentence

Dragsten (2004) stated learning strategies refer to the characteristic to stimulate the students to be more proficient language learners-strategies are specific means that learners use to learn or improve their language. Furthermore, Chen (2005) also stated learning strategies are mental processes that students can consciously control when they have a learning goal.

Male students in Malaysia used strategies more often than females when they were learning a language (Shukri et al., 2009). Besides, a study by Sundari and Dasmo (2014) found that the results for strategy categories showed male students, surprisingly, used significantly more social strategies than female students and male students used slightly more memory, cognitive, and metacognitive strategies than female students. Shortly, Language Learning Strategies (LLS) is defined as the conscious thoughts and actions that learners take in order to achieve a learning goal (Radwan, 1990).

In accordance with the importance of English for communication, the Indonesian government has endeavored to improve the system of education and human resources development in realizing the objectives of national education. The curriculum of English for vocational school is based on the notional and functional syllabus. There is a requirement for vocational students to acquire communicative competence in English. The students can express the meaning well with the appropriate form, such as, in grammar, pronunciation, and vocabulary. One of the weaknesses which they have in learning English is speaking ability is still low. The indicators of the problems are as follows: First, the students are shy to express their ideas in English. Second, the students seem to be in doubt and nervous to speak

Premise Journal Vol. 8 No 1, April 2019, e-ISSN: 2442-482x, p-ISSN: 2089-3345, page 57-72 Copyright@2019 by PJE 
English; Third, the students do not know how to apply different transactional and interactional expressions in different situations. Fourth, the students are afraid of making mistakes in grammar, pronunciation, and intonation. Fifth, the students are afraid to be laughed at by others and they have no courage to express their own English ability; and finally, they never use English in their daily communication either inside. Gee and Handford (2012) stated vocational degrees are kind of meeting ground between profession and education. It means that they provide the opportunity to earn a fast-paced education directly related to a vocation or skill set. Like most degrees, the vocational degree is designed to prepare the student for the workforce where he or she will start a career.

Hence, the researchers think that learning strategies are worth to be applied in learning a second/foreign language, English. Learning strategies are techniques, approaches or deliberate actions that students take in order to facilitate the learning and recall of both linguistic and content area of information. In other words, strategies here are consciously selected and used by male and female students. Moreover, the selection of learning strategies will differ among students especially the tenth-grade students of SMKN Karangpucung as they have been learning English since elementary school. The researchers are interested to find out what learning strategies are usually used between male and female students and to investigate which learning strategies used by male and female students dominate in learning speaking. This research has benefits to analyze the learning strategies used by male and female students and it will help to improve students speaking ability in SMKN Karangpucung by giving different learning strategies for male and female students.

\section{Research Question}

This research is guided by the following research questions.

1. What is a learning strategy used by male and female students in learning speaking?

2. Which learning strategies are dominantly used by male and female students?

Premise Journal Vol. 8 No 1, April 2019, e-ISSN: 2442-482x, p-ISSN: 2089-3345, page 57-72 Copyright@2019 by PJE 


\section{RESEARCH METHOD}

\section{Design}

This research used a qualitative method. Qualitative research is the collection, analysis, and interpretation of comprehensive narrative and visual data in order to gain insights into a particular phenomenon of interest (Larsson 2017; Hallas 2008; Reidy 2013). The survey research designs enable researchers to describe or present the picture of a phenomenon or phenomena under investigation. This type of method is also a grouping that includes many particular research methodologies and procedures, such as observations, surveys, self-reports, and tests.

\section{Participants}

In this research, the researcher took 32 students of tenth grade in Automotive and Accountancy Program as a sample by using purposive sampling from total number 320 students of SMK Negeri Karangpucung. Because only Automotive and Accountancy Program are complete of male and female students.

\section{Instruments}

As a matter of fact, there were several kinds of instruments to obtain the researchable data in a study. Considering the requirement and the purpose of this research, the researcher used a camera to capture and see what going on during the activity (teaching and learning process), and how both teacher and students conduct in learning speaking. Furthermore, the researcher used a closed questionnaire. On the other word, the questionnaire is a set of states that is used to collect the data for the research. It is very important to collect the data, because the result of this questionnaire will be presented in numbers, tables, and draw a conclusion.

This research used a closed questionnaire. The total statements of a closed questionnaire Strongly Agree, Agree, Neutral, Disagree, and Strongly Disagree. It is used to obtain the information on students' perception toward the strategies are used by male and female students in learning speaking.

Premise Journal Vol. 8 No 1, April 2019, e-ISSN: 2442-482x, p-ISSN: 2089-3345, page 57-72 Copyright@2019 by PJE 
The classification of strategies consists of 30 statements covering: a) Cognitive Strategies: These help learners understand and produce new language through practicing, summarizing, reasoning deductively, and analyzing (e.g., repeating, taking notes). b) Affective Strategies: These strategies help learners through lowering their anxiety levels, increasing their motivation, and controlling their emotions (e.g., discussing feelings with others, using music to lower anxiety). c)Metacognitive Strategies: These help learners control their learning through monitoring their language use, planning, coordinating the learning process, and looking for opportunities to use the language (e.g., linking new information with old information, self-monitoring, planning, evaluating, and seeking practice opportunities). d) Social Strategies: These help learners to interact, communicate, cooperate, and empathize with others to maximize learning (e.g., developing cultural understanding, cooperating with others).

\section{Data Collecting Technique}

In this research, the researcher had been done the steps as follow: asking for permission to the Headmaster and English teachers of SMK Negeri Karangpucung, the researcher gave some questionnaire for the students at the tenth grade of SMK Negeri Karangpucung to get the data, the data obtained from the questionnaire was analyzed in a narrative way. The last is drawing the conclusion.

\section{Data Analysis Technique}

The purpose of analyzing the data is to find the meaning of the data and this is done systematically by arranging to present the information. After the data have been collected and compiled, the researchers analyzed the data with the following steps: a) The data are organized by using survey study, then describing the data in detail, clarifying the terms, and then interpreting the result. b) After distributing the questioners to the students, the data analyzed in a narrative way to obtain the students' responses, it means male and female students' strategies in learning speaking. c) Calculating the score of all respondents from the questionnaire. In this step, the

Premise Journal Vol. 8 No 1, April 2019, e-ISSN: 2442-482x, p-ISSN: 2089-3345, page 57-72 Copyright@2019 by PJE 
researcher used formula by Hatch \& Lazaraton (1991). d) Drawing a conclusion from the result of the questionnaire.

\section{RESULT AND DISCUSSION}

The research data were derived from the questionnaire. In calculating the data, the researcher treated them by means of techniques of describing the data from the questionnaire in order to find the out the male and female students' strategies in learning speaking in analyzing the students respondent, the researcher describes the data. The detailed information for each question of the questionnaire is presented in the following data taken from observation.

\section{Result}

In calculating the data, the researchers gave questionnaires in order to find out the information on students' perception toward the strategies are used by male and female students in learning speaking. Then the students' responses were put in percentage can be seen in the table below.

This table identified the learning strategies are used by male and female students in learning speaking. The following table has presented an analysis of Male Cognitive, Affective, Metacognitive, and Social aspect.

Table 1. The Data Obtained from Questionnaire Based on Male Cognitive, Affective, Metacognitive, and Social aspect.

\begin{tabular}{|c|c|c|c|c|c|}
\hline Number & SA & A & N & D & SD \\
\hline \multicolumn{7}{|c|}{ Cognitive } \\
\hline Average & $10,23 \%$ & $31,82 \%$ & $47,73 \%$ & $9,66 \%$ & $0,57 \%$ \\
\hline \multicolumn{6}{|c|}{ Affective } \\
\hline Average & $20 \%$ & $26,25 \%$ & $41,25 \%$ & $7,5 \%$ & $5 \%$ \\
\hline \multicolumn{7}{|c|}{ Metacognitive } \\
\hline Average & $21,88 \%$ & $48,44 \%$ & $26,56 \%$ & $3,13 \%$ & $0 \%$ \\
\hline \multicolumn{7}{|c|}{ Social } \\
\hline Average & $8,33 \%$ & $39,58 \%$ & $42,71 \%$ & $8,33 \%$ & $1,04 \%$ \\
\hline
\end{tabular}

Based on the table, the cognitive aspect shows there were $10,23 \%$ students answering SA (Strongly Agree) on the statement of "I try to translate English words

Premise Journal Vol. 8 No 1, April 2019, e-ISSN: 2442-482x, p-ISSN: 2089-3345, page 57-72 Copyright@2019by PJE 
into Bahasa based on people said to know its meaning”. There were 31,82\% students answering A (Agree) on the statement of "I use English words based on my understanding". There were 47,73\% students answering N (Neutral) on the statement of "I start to speak English and I make the summary in English based on what I've heard and read". There were 9,66 \% students answering D (Disagree) on the statement of "I try to watch English TV Program or movie". There were 0,57 \% students answering SD (Strongly Disagree) on the statement of "I try to speak English with native speakers".

Then, the aspect of affective shows there were $20 \%$ of students answering SA (Strongly Agree) on the statement of "I appreciate myself when I can speak English well". There were 26,25\% students answering A (Agree) on the statement of "I am confident enough to speak English". There were 41,25\% students answering N (Neutral) on the statement of "I motivate myself to speak English when I am afraid to make mistake”. There were 7,5\% students answering D (Disagree) on the statement of "I am nervous when I speak English so I tell it to my friend to make me comfort". There were $5 \%$ of students answering SD (Strongly Disagree) on the statement of " $I$ am giving up to speak English".

Furthermore, the research result of Metacognitive aspect shows there were 21,88\% students answering SA (Strongly Agree) on the statement of "My goal is to improve my English". There were 48,44 \% students answering A (Agree) on the statement of "I give my big attention in Speaking English". There were 26,56 \% of students answering $\mathrm{N}$ (Neutral) on the statement of "I show to my friend that I can speak English". There were 3,13\% students answering D (Disagree) on the statement of "I inform to a public that I can speak English".

Based on the social aspect, the research result shows there were 8,33\% students answering SA (Strongly Agree) on the statement of "When I do not know what people said when I ask them to speak slowly". There were 39,58 \% students answering A (Agree) on the statement of "I ask my friend who masters in English to be my partner for practicing". There were $42,71 \%$ students answering N (Neutral) on the statement of "I am always asking something in English". There were 8,33\%

Premise Journal Vol. 8 No 1, April 2019, e-ISSN: 2442-482x, p-ISSN: 2089-3345, page 57-72 Copyright@2019 by PJE 
students answering D (Disagree) on the statement of "I am always using English in my daily life ". And there were 1,04 \% students answering SD (Strongly Disagree) on the statement of "I am always communicating in English".

The following table has presented an analysis of female Cognitive, Affective, Metacognitive, and Social aspect.

Table 2. The Data Obtained from Questionnaire Based on Female Cognitive, Affective, Metacognitive, and Social aspect

\begin{tabular}{|c|c|c|c|c|c|}
\hline Number & SA & A & N & D & SD \\
\hline \multicolumn{7}{|c|}{ Cognitive } \\
\hline Average & $15,91 \%$ & $31,82 \%$ & $40,91 \%$ & $11,36 \%$ & $0 \%$ \\
\hline \multicolumn{7}{|c|}{ Affective } \\
\hline Average & $24,9 \%$ & $38,75 \%$ & $28,75 \%$ & $7,5 \%$ & $0 \%$ \\
\hline \multicolumn{7}{|c|}{ Metacognitive } \\
\hline Average & $28,91 \%$ & $41,41 \%$ & $20,31 \%$ & $7,03 \%$ & $2,34 \%$ \\
\hline \multicolumn{7}{|c|}{ Social } \\
\hline Average & $19,79 \%$ & $28,13 \%$ & $42,71 \%$ & $9,38 \%$ & $0 \%$ \\
\hline
\end{tabular}

Based on the table, the research result of Cognitive aspect shows there were 15,91\% students answering SA (Strongly Agree) on the statement of "I try to translate English words into Bahasa based on people said to know its meaning". There were 31,82\% students answering A (Agree) on the statement of "I do the pronunciation practice". There were 40,91\% students answering $\mathrm{N}$ (Neutral) on the statement of "I try to speak English with native speakers". There were 11,36\% students answering D (Disagree) on the statement of "I write message, letter or report in English".

Besides, the research result of Affective aspect shows there were 24,9\% students answering SA (Strongly Agree) on the statement of "I appreciate myself when I can speak English well”. There were 38,75 \% students answering A (Agree) on the statement of "I appreciate myself when I can speak English well". There were $28,75 \%$ students answering $\mathrm{N}$ (Neutral) on the statement of "I motivate myself to speak English when I am afraid to make mistake". There were 7,5\% students answering D (Disagree) on the statement of "I am nervous when I speak English so I tell it to my friend to make me comfort".

Premise Journal Vol. 8 No 1, April 2019, e-ISSN: 2442-482x, p-ISSN: 2089-3345, page 57-72 Copyright@2019 by PJE 
Then, based on the research result of Metacognitive aspect shows there were 28,91\% students answering SA (Strongly Agree) on the statement of "I use my mistakes to be better". There were 41,41 \% students answering A (Agree) on the statement of "I give my big attention in Speaking English". There were 20,31\% students answering N (Neutral) on the statement of "Thinks first, talk after". There were $7,03 \%$ of students answering D (Disagree) on the statement of "I show to my friend that I can speak English". There were 2,34 \% students answering SD (Strongly Disagree) on the statement of "I inform to a public that I can speak English".

Besides, the research findings of Social aspect shows there were 19,79\% students answering SA (Strongly Agree) on the statement of "I ask my friend who masters in English to be my partner for practicing". There were 28,13\% students answering A (Agree) on the statement of "When I do not know what people said when I ask them to speak slowly". There were $42,71 \%$ students answering $\mathrm{N}$ (Neutral) on the statement of "I practice speaking English with my friend". There were 9,38\% students answering D (Disagree) on the statement of "I am always asking something in English".

Having finished analyzing each learning strategies of male and female students' questionnaire, the researcher tried to find out the dominant strategy used by male and female students' refers to the table below:

Table 3. The result of Male and Female Students' Strategies in Learning Speaking of the Questionnaire

\begin{tabular}{|c|c|c|c|c|c|}
\hline \multicolumn{7}{|c|}{ Male Students } \\
\hline No. & Cognitive & Affective & Metacognitive & \multicolumn{2}{|c|}{ Social } \\
\hline 1. & SS $: 10,23 \%$ & SS $: 20 \%$ & SS $: 21,88 \%$ & SS $: 8,33 \%$ \\
\hline 2. & S $: 31,82 \%$ & S $: 26,25 \%$ & S $: 48,44 \%$ & S $: 39,58 \%$ \\
\hline 3. & NT $: 47,73 \%$ & NT $: 41,25 \%$ & NT $: 26,56 \%$ & NT $: 42,71 \%$ \\
\hline Total & $89,78 \%$ & $87,5 \%$ & \multicolumn{2}{|c|}{$96,88 \%$} & $90,62 \%$ \\
\hline \multicolumn{7}{|c|}{ Female Students } \\
\hline No. & Cognitive & Affective & Metacognitive & Social \\
\hline 1. & SS $: 15,91 \%$ & SS $: 24,9 \%$ & SS $: 28,91 \%$ & SS $: 19,79 \%$ \\
\hline 2. & S $: 31,82 \%$ & S $: 38,75 \%$ & S $: 41,41 \%$ & S $: 28,13 \%$ \\
\hline 3. & NT $: 40,91 \%$ & NT $: 28,75 \%$ & NT $: 20,31 \%$ & NT $: 42,71 \%$ \\
\hline Total & $88,64 \%$ & $92,4 \%$ & $90,63 \%$ & $90,63 \%$ \\
\hline
\end{tabular}

Premise Journal Vol. 8 No 1, April 2019, e-ISSN: 2442-482x, p-ISSN: 2089-3345, page 57-72 Copyright@2019 by PJE 
Based on the table, the researchers conclude that male students use Metacognitive strategy $(96,88 \%)$ in learning speaking and female students use Affective Strategy $(92,4 \%)$ in learning speaking. On the other hand, it can also be said that the Metacognitive Strategy is dominantly used by Male students, and Affective Strategy is dominantly used by Female students.

\section{Discussion}

This section explores the discussions based on the research findings in the previous chapter. Then, it can be started by answering the research question about the learning strategy used by male and female students in learning speaking. Male students used more metacognitive strategies than female students. It means that male students are always planning and evaluating the language before doing conversation. And female students used effective strategies. It means that female more focused on emotions, attitudes, and motivations before or during the conversation.

The result of the research is male students used more metacognitive strategies than female students and female students used effective strategies. In the other word, female especially tended to use effective strategies more frequently than male and one of the strategies more frequently used by female students than metacognitive, social, and cognitive strategies (Shukri et al.,2009; Zhou, 2010). A further example, Zhou said that students try to relax whenever they feel afraid of using English and they encourage their self to speak in English even when they are afraid of making a mistake. Another reason may be that females are more stable than males in attitude and learning motivation because they are more mature in physical and psychological development. Females are willing to work hard and use learning strategies to improve their learning while males are indulgent in playing. Besides, according to Irawati (2008) in having a presentation or speaking in English, male students use mostly metacognitive strategies. For example, they try to find as many ways as they can to use English and they plan their schedule so they will have enough time to study English. Another reason may be that male wants to get clear goals for improving their speaking skill than female students. It can be said that the Metacognitive Strategy is

Premise Journal Vol. 8 No 1, April 2019, e-ISSN: 2442-482x, p-ISSN: 2089-3345, page 57-72 Copyright@2019 by PJE 
dominate used by male students, and Affective Strategy is dominate used by Female students.

Based on the result findings of the present study and the previous research, the researcher concludes that male students used more metacognitive strategies than female and female students used more effective strategies than male in learning speaking at the tenth grade of SMKN Karangpucung. So, it can also be said that Metacognitive Strategies are dominantly used by male students, and Affective Strategies are dominantly used by Female students.

\section{CONCLUSION}

After analyzing the data, the researcher comes to the conclusion of the research. Based on the data that have been gathered from the questionnaire, the researcher concludes that strategies used by male and female students' at SMKN Karangpucung are as follow: a) Male students tend to used more Metacognitive strategies than do the female students and Female students tend to used Affective strategies in learning speaking at the tenth grade of SMKN Karangpucung. b) Metacognitive strategies used by male students dominate than female and Affective strategies used by female students dominate than male in learning speaking at the tenth grade of $S M K N$ Karangpucung. c) Gender affects learning strategies conducted by male and female students in learning speaking, especially at the tenth grade of SMKN Karangpucung.

\section{BIO-PROFILE}

Adelina Anum holds her bachelor in English Education from the University of Muhammadiyah Metro and her Master degree in English Education from University of Ahmad Dahlan, Yogyakarta. She is now a lecturer in Universitas Sang Bumi Ruwa Jurai Bandar Lampung, Her research interests are English Language Teaching, Social, and Linguistics.

\section{BIO-PROFILE}

Sigit Apriyanto holds his bachelor in English Education from University of Galuh, and his Master degree in English Education from University of Ahmad Dahlan,

Premise Journal Vol. 8 No 1, April 2019, e-ISSN: 2442-482x, p-ISSN: 2089-3345, page 57-72

Copyright@2019 by PJE 
Yogyakarta. Now, he is studying at Doctor of Philosophy - Universiti Tun Hussein Onn Malaysia, under faculty of Applied Science and Technology. His research interests include gender, discourse analysis, and forensic linguistics.

Premise Journal Vol. 8 No 1, April 2019, e-ISSN: 2442-482x, p-ISSN: 2089-3345, page 57-72 Copyright@2019by PJE 


\section{REFERENCES}

Aslan, O. (2009). The role of gender and language learning strategies in learning English. Unpublished Master's Thesis, (September).

Baalen, I. van. (2001). Male and female language_growing together? Retrieved from http://www.let.leidenuniv.nl/hsl_shl/van Baalen.htm

Boeriswati, E. (2012). The Model of Speaking in Teaching Indonesian to Foreign Speakers Based on Self-Regulated Learning and Anxiety Reduction Approaches. Sino-US English Teaching, 9(5), 1154-1163. Retrieved from http://search.proquest.com/docview/1323346350?accountid=14548\%5Cnhttp:// metadata.lib.hku.hk/hku?url_ver=Z39.882004\&rft_val_fmt=info:ofi/fmt:kev:mtx:journal\&genre=article\&sid=ProQ:ProQ: llba\&atitle $=$ The + Model + of + Speaking + in + Teaching + Indonesian + to+Foreign + Sp

Chen, Y. (2005). THE LEARNING STRATEGIES OF TAIWANESE UNIVERSITY STUDENTS : ENGLISH MAJORS VERSUS NON-ENGLISH MAJORS AND MALES VERSUS FEMALES, 1(2), 203-219.

Dragsten, M. (2004). Strategies for Learning English as a Foreign Language. South Korea.

Gee, J. P., \& Handford, M. (2012). The Routledge Handbook of Discourse Analysis. The Routledge Handbook of Discourse Analysis. https://doi.org/10.4324/9780203809068.ch7

Hallas, J. (2008). Rethinking teaching and assessment strategies for flexible learning environments. Ascilite 2008, (1992), 10-11. Retrieved from http://ascilite.org.au/conferences/melbourne08/procs/hallas.pdf

Hanna Sundari, \& Dasmo. (2014). the Effect of Speaking Self-Efficacy and Gender in Speaking Activities. Bahasa Dan Sastra, 14, No. 2(2), 205-217. Retrieved from http://ejournal.upi.edu/index.php/BS_JPBSP/article/view/719/519

Hatch, E., \& Lazaraton, A. (1991). Design and Statistics for Applied Linguistics. United States: Heinle \& Heinle Publisher.

Irawati, L. (2008). LEARNING STRATEGIES USED BY DIFFERENT GENDER IN SPEAKING CLASS OF IKIP PGRI MADIUN. Sebelas Maret University.

Kiesling, S. F. (2008). Prestige, Cultural Models, and Other Ways of Talking About Underlying Norms and Gender. The Handbook of Language and Gender, 509527. https://doi.org/10.1002/9780470756942.ch22

Larsson, K. (2017). Understanding and teaching critical thinking-A new approach. International Journal of Educational Research, 84(June), 32-42. https://doi.org/10.1016/j.ijer.2017.05.004

Premise Journal Vol. 8 No 1, April 2019, e-ISSN: 2442-482x, p-ISSN: 2089-3345, page 57-72 Copyright@2019by PJE 
Radwan, A. A. (1990). Effects of L2 proficiency and gender on a choice of language learning strategies by university students majoring in English. Asian EFL Journal, 115-163.

Reidy, C. G. (2013). Students' Awareness of Gender Dynamics in the College Classroom.

Romaine, S. (2008). Variation in Language and Gender. The Handbook of Language and Gender, 98-118. https://doi.org/10.1002/9780470756942.ch4

Sabbatini, R. M. E. (1997). Are There Differences between the Brains of Males and Females? Brazil: State University of Campinas. Retrieved from http://www.cerebromente.org.br/n11/mente/eisntein/cerebro-homens.html

Saputra, J. B. (2018). an Analysis of Students' Speaking Anxiety Toward Their Speaking Skill. Premise : Journal of English Education and Applied Linguistics, 7(1), 111-123. https://doi.org/doi.org/10.24127/pj.v7i1.

Shukri, K., Teh, M., Embi, M. A., Mohd, N., Nik, R., \& Mahamod, Z. (2009). A Closer Look at Gender and Arabic Language Learning Strategies Use, 9(3).

Umar. (2018). STUDENTS' SPEAKING MOTIVATION IN LEARNING. Premise : Journal of English Education and Applied Linguistics, 7(1), 57-67. https://doi.org/doi.org/10.24127/pj.v7i2.

Zhou, Y. (2010). English Language Learning Strategy Use by Chinese Senior High School Students, 3(4), 152-158.

Premise Journal Vol. 8 No 1, April 2019, e-ISSN: 2442-482x, p-ISSN: 2089-3345, page 57-72 